\title{
O imaginário das nomadologias em Guimarães Rosa e Milton Hatoum
}

Amilton José Freire de Queiroz ${ }^{1}$

\begin{abstract}
This article examines the imagery of the multiterritorial nomadologies in Orientação, of Guimarães Rosa, and Um oriental na vastidão, of Milton Hatoum, conceiving them as textual spaces where the perspective of the cross-cultural and intercultural movement is combined to represent citizenships, transfers and interplanetary exchanges.
\end{abstract}

Keywords: nomadologies; multiterritories; imaginary; literature.

Resumo: Este artigo examina o imaginário das nomadologias multiterritoriais nos contos Orientação, de Guimarães Rosa, e Um oriental na vastidão, de Milton Hatoum, concebendo-os como espaços textuais onde estão conjugadas a perspectiva do movimento transcultural e intercultural para figurar cidadanias, transferências e trocas interplanetárias.

Palavras-chave: nomadologias; multiterritórios; imaginário; literatura.

Introdução

O diálogo entre Literatura, Geografia e Imaginário tem impulsionado a expansão das epistemologias plurais como estratégia para inspecionar a dinâmica das culturas transfronteiriças no texto literário e seu intercâmbio com a geograficidade do agora. Nesse sentido, abordar a literatura em perspectiva global significa revisitar a vocação transnacional da narrativa contemporânea, compreendendo o modus operandi da (re)invenção de cidadanias solidárias pautadas pelos trânsitos.

A rede interativa entre as culturas geográfica e literária contribui, de um lado, para a redefinição do "modo de estar no mundo, um tanto fora do lugar, outro tanto à margem, propicia novas matizes e formas de percepção" (CHIARELLI, 2016, p. 105). As cartografias do imaginário facultam, de outro lado, a montagem de um mosaico das marcas da diferença. A redefinição do estar mundo dá-se a partir da recepção de uma geopoética e uma geocrítica instalada na compreensão dos "valores e significações de seu imaginário mais íntimo, portador de um potencial considerável de invenção linguística e formal", (COLLOT, 2012, p.29). Essas escalas transversais afinam-se à perspectiva do afrontamento de espaços, línguas e culturas, tornando viável o deslocamento pelas vias de uma geografia literária embalada pela itinerância do homem no mundo das trocas culturais.

Modulando na frequência das transferências intercontinentais, a narrativa contemporânea hospeda, portanto, o meridiano do "tecido de uma relação, relação esta que se define pelo olhar. Uma ponte, feita de palavras, envolve a experiência muda do olhar e

1 Amilton José Freire de Queiroz é Professor Adjunto II da Universidade Federal do Acre, lotado no Colégio de Aplicação. É doutor em Literatura Comparada pela UFRGS e pós-doutorando em Teoria da Literatura e Literatura Comparada pela UFMG. 
torna possível a narrativa”. (SANTIAGO, p. 2002, p.52). Do olhar em trânsito do narrador ao deslocamento das personagens, a narrativa cartografa a imprevisibilidade onde "as passagens intersticiais e os processos de diferença cultural estão inscritos no entre-lugar, na dissolução temporal que tece o texto global" (BHABHA, 1998. p.298). A cosmovisão do texto global circunscreve-se nos limites intrínsecos de epistemologias narrativas sobre o "desassossego, o movimento constante, o deslocamento, a partir dos quais uma experiência é sempre contraposta a outra, fazendo com que ambas apareçam sob uma luz nova e imprevisível" (SAID, 2005, p. 67).

Posicionada no diálogo intervalar, a narrativa contemporânea transita, desloca e reconecta o mundo físico, social, cultural e estético, projetando o imaginário de "uma geografia transfronteiriça que é ao mesmo tempo uma geografia da mediação e uma geografia das redes” (BESSIÉRE, 2011, p. 33). Dos meridianos do texto à cartografia das diferenças, delineia-se uma poética lítero-geográfica alicerçada em três rotas de trânsitos: a língua-alteridade, a escrita-devir e a territorialidade-humanidade. Esse triunvirato expande o circuito metafórico e metonímico do imaginário. Destarte, a poética lítero-geográfica potencializa as epistemologias transfronteiriças, frisando a espessura da releitura, reescrita e ressemantização do processo de narrativização do presente. Nela, encontram-se os sinais do contato intercultural, intertextual, intersemiótico, transterritorial, interterritorial e multiterritorial do mundo, narrado, poetizado e dramatizado através da expansão do pensamento complexo.

A poética lítero-geográfica explora o trânsito teórico-metodológico como princípio para compreender o "território, como espaço dominado e/ou apropriado, manifesta hoje um sentido multi-escalar e multi-dimensional que só pode ser devidamente apreendido dentro de uma concepção de multiplicidade, tanto no sentido da convivência de "múltiplos" (tipos) de território quanto da construção efetiva da multiterritorialidade" (HAESBAERT, 2008, p. 106). Assim compreendida, as narrativas onde se instauram a poética lítero-geográfica escalam a textura das relações interplanetárias, com o exercício da transumância intelectual assentada na realização de uma geocrítica do eurocentrismo cuja voltagem crítica problematiza "as representações metonímicas da dimensão transfronteiriça” (MATA, 2012, p. 141). O complexo cultural das cidadanias interfere no traçado da interconexão global, "juntando ao presente essas rotas fragmentárias, frequentemente ilegais, e reconstruir suas genealogias não ditas" (HALL, 2013, p.46). A topografia das genealogias silenciadas instaura, primeiramente, os rastros da língua-alteridade em constante mutação.

O deslocamento da língua-alteridade, nos meridianos do texto, adéqua-se ao pensamento de que "este é o devir da língua: não há criação de palavras, não há neologismos que tenham valor fora dos efeitos de sintaxe em que se desenvolvam" (DELEUZE, 2006, p. 36). Nessa perspectiva, a língua revela-se enquanto multiterritorialidade instável para desobstruir os trilhos da relação intercomunicativa com a consciência do exílio na contemporaneidade. Partindo da percepção de que "o sujeito é também alteridade, carrega em si o outro, o estranho, que o transforma e é transformado por ele" (CORACINI, 2007, p. 17), a língua-alteridade mobiliza fluxos híbridos e captura a semioses nômades, orbitando na premissa de que "aprender uma língua é sempre, um pouco, tornar-se outro" (REVUZ, 1998, p. 45). A língua-alteridade, destarte, alberga-se no texto literário como margem onde se espraiam as ambiguidades do encontro de línguas provisórias.

Desse caráter de oblíquo da língua decorre o segundo rastro da poética lítero-geográfica: os meridianos da narrativa contemporânea como escrita-devir, conjugando o movimento de "estar fora do texto ou dentro, ou ainda, atravessá-lo por um olhar, tocá-lo, tan- 
genciando línguas e linguagens em busca de uma leitura possível " (CASA NOVA, 2008, p. 107). Por trás, por baixo e por cima do olhar, o plural da escrita-devir configura-se através do jogo das representações culturais, apontando como as noções de duplicidade e gestualidade unitária têm seus fundamentos abalados pela triangulação do pensamento meditativo, cujo laboratório circunstância a indissociabilidade entre contexto, leitores e leituras das multiterritorialidades.

Transitando pelos "quadros de referência da circulação e aquisição do saber cultural e literário e modos de ver, modos de julgar descrições e prescrições” (JOBIM, 2005, p. 8), a narrativização do mundo a partir da escrita-devir transporta os leitores para dentro e fora do texto. Na dianteira dessa visão heteróclita, os limites da interpretação são rompidos para permeabilizar o pensamento crítico que elabora outras bússolas de leitura, com ponteiros enraizados dinamicamente na constelação das reticências. Isto é, franquear a aventura do trânsito na estrangeiridade para traduzir os afetos que interconectam o mundo solidariamente na narrativa contemporânea.

Nos meandros da diferença, a escrita-devir transforma-se em uma territorialidade- humanidade, completando, assim, o terceiro traço transfronteiriço do "espaço contemporâneo de negociação de identidades constitutivamente construído na diversidade e no hibridismo próprio de todas as culturas" (CURY, 2016, p. 148). O pensamento homogêneo é questionado nas flutuações do espaço em sua condição intervalar, fissurando os espartilhos das semelhanças, de tal forma a promover a circulação de "estéticas transculturais, abertas a interações e, por consequência, à criação do novo ” (BERND, 2013, p. 215). O grau das dessemelhanças serve também para instanciar os fluxogramas das tensões dos imaginários, constituindo uma multiterritorialidade textual catalizadora do exercício de outridades.

Afinal, a topografia do encontro das humanidades, nos meridianos da narrativa, permite "questionar e problematizar a experiência literária nesses espaços, nesses lugares do trânsito cultural no qual habitam os vários estrangeiros, os vários sujeitos em trânsito, vários outros e outras" (ALMEIDA, 2009, p. 72). O fluxograma da humanidade em transformação nasce, assim, das memórias, com seus intervalos traduzidos para além do pertencimento absoluto. $\mathrm{O}$ verbo pertencer, em tal perspectiva, encontra-se declinado na linha do relativo, haja vista integrar a marca de vozes, saberes e subjetividades de mundos em conexão.

Com isso, estabelece-se uma redefinição de horizontes não mais alicerçados na separação dos limites do pertencimento; ao contrário, o acesso às redes do humano em trânsito acha-se acometido pela "estratégia de discursiva, que associa visibilidade, espaço, a abertura” (GOMES), 2015, p. 279) às solidariedades híbridas do contemporâneo. Conforme o desdobramento do olhar em trânsito, a territorialidade-humanidade retraça e relança outros pontos de interrogação, para que o congresso de culturas, línguas e geograficidades tenha autonomia para revisitar os espaços de enunciação onde o sujeito realiza as performances do abalo sísmico de eurocentrismos, americanizações e latinizações.

As revisitações a essa instância interventiva têm, outrossim, o escopo de apontar as caligrafias de outros espaços forjados desde a proposição, consecução e autogestão crítica de roteiros intercomunicativos. Os espaços de vacância se apresentam como intercruzamentos que giram ao redor da ética alheia, trazendo consigo a cartografia das humanidades em deslocamento como veículo para "analisar a rede de poder que organiza conteúdos e que, ao organizar, classifica e valoriza, definindo o que importa ser visto e que deve ser descartado como sobra destinada à invisibilidade cotidiana" (MARGATO, 2015, p. 122). A força da territorialidade-humanidade concretiza-se no espectro das leituras cruzadas, pressupondo diferença, mas também pontos de convergência. 
Os resíduos da passagem ficam impressos na memória do sujeito, com "seus espaços habitados e seus lugares precários a serem descobertos e apropriados, mesmo que de modo provisório" (PORTO, 2012, p. 128). Nos meridianos do texto global, instala-se, prospectivamente, a diversidade de vozes, sujeitos e perspectivas, afrontando as fronteiras de continentes, saberes e culturas para promover, por consequência, uma transversalidade de fraturas moleculares consubstanciadas à fuga das palavras estereotipadas.

Através da plurivocalidade ética, consolidam-se as escalas multissemânticas "de como as diferenças culturais proliferam e mudam ao longo do tempo, alterando significados políticos das identidades culturais" (GARRAMUÑO, 2000, p. 80). Em tal linha interpretativa, os meridianos da poética lítero-geográfica ligam-se às redes do texto plural, singularizado pela nomadologia de alteridades rizomáticas nas epistemologias narrativas contemporâneas.

A leitura da mobilidade tem produzido, positivamente, (dis)fonias cuja rasura busca dar corpo às discrepâncias de pontos de vista, fazendo girar os meridianos do texto para flagrar as fraturas moleculares e tornar transversal as territorialidades existenciais. O deslocamento pelos estratos das interações aponta para uma pedagogia intervalar costurada por mediadores culturais hospedados no terminal da voz órfão das certezas, permitindo a trafegabilidade de sotaques egressos da marcha de textos, contextos e epistemologias descentrados.

As redes do (geo) texto redesenham-se, portanto, nas nomadologias multiterritoriais da língua, alteridade e epistemologias transfronteiriças. Como escala transterritorial, a prosa literária transita no imaginário da circunvizinhança para rastrear, de um lado, as experiências do contato e traduzir, de outro lado, os resíduos das interculturalidades. Sendo assim, o papel dos escritores reveste-se de cabal importância para compreender as culturas em movimento.

A realização do pensamento transfronteiriço sinaliza, contumazmente, para a efetivação do panorama das mutações discursivas e do espessamento das fronteiras, adensando o mapeamento de afeto, ansiedade, medo, insegurança suscitados através das situações-limítrofes vividas pelo sujeito contemporâneo.

\section{Nomadologias multiterritoriais}

Tecidas pelas constelações polifônicas, as obras Tutaméia-terceiras estórias, de Guimarães Rosa, e A cidade ilhada, de Milton Hatoum, escalam as filigranas do imaginário oriental na trama de Orientação e Um oriental na vastidão. Nestes contos, o leitor transita pela solidariedade de vidas situadas no entre-lugar dos pertencimentos relativos, bem como traduz o movimento do "próprio e alheio no percurso literário brasileiro" (CARVALHAL, 2003, p. 125) como uma linha fuga onde "se desencadeiam, sob os princípios da hibridez e da heterogeneidade, múltiplas combinações, metamorfoses, convergências " (FANTINI, 2003, p. 106) das nomadologias multiterritoriais.

Temática e esteticamente, nos dezoito parágrafos do conto do autor mineiro, configura-se a cartografia para além da "puridade de verdade” (ROSA, 1979, p. 108), dando vazão à itinerância de Yao Tsing-Lao e Rita Lola no "meio de Minas Gerais” (ROSA, 1979, p. 108), figurada como territorialidade cujas matrizes estampam percepções em permanente expansão. O início da perspectiva do trânsito se desenrola no emprego das formas nominais "vindo, vivido e ido" (ROSA, 1979, p. 108) a respeito de Joaquim, mais conhecido como 
Quim. Entre a trafegabilidade do gerúndio e particípio, o narrador mediador desdobra microfilamentos que se entrecruzam na trajetória de Quim e Rita Lola, interligando horizontes de expectativa distribuídos em uma variação contínua do sertão-mundo. A afirmação de que "tudo cabe no globo" (ROSA, 1979, p. 108) demonstra a consciência plural de Quim, fazendo-o habitar a liminaridade do sertão da cultura em errância.

Pela escavação das temporalidades, a afirmação de que "o mundo do rio não é o mundo da ponte" (ROSA, 1979, p. 108) denuncia a agudeza transterritorial do narrador. O espaço do rio é transformado pela chegada da ponte, adulterando o percurso da travessia de uma margem a outra. Sendo assim, Quim transmigra entre vivências concentradas na estrangeiridade, ressoada no prisma profícuo da dúvida. Desde o aprendizado da língua portuguesa, o chinês desliza na prosódia do nome da brasileira, em lugar de enunciar Rita Rola, projeta a dicção rasurada de Lola-a-Lita. O rio da língua atravessado por Quim se expande em distintas marcas de estrangeiridade, tendo de escorregar pela superfície da voz como territorialidade cuja fricção fonológica cavalga em parceria com a produção de outras relações morfossintáticas, mas especialmente fatos de linguagem assentados no fomento de outras brechas semânticas.

Essas se tornam mais exequíveis no casamento entre Quim e Rita, principalmente com a instigante imagem "o par - o compimpo - til no i, pingo no a, o que de ambos, parecidos como uma rapadura e uma escada” (ROSA, 1979, p. 109). Figura-se aí um intervalo semântico de rearranjo da semivogal $i$ e a mudança da região de colocação do pingo na vogal a. A transmodelação da língua completa-se dialogicamente na rearticulação da variabilidade do universo dos falantes. Da fonologia, o narrador migra para a semântica da "rapadura e escada" (ROSA, 1979, p. 108), conotando a conjunção do aspecto alimentar à mobilidade do tempo de desencontro de Quim e Rita. A mobilidade dos dois protagonistas escorre pelo mundo do narrador diante de sua perspicácia de vaticinar “a válida intraduzibilidade" (ROSA, 1979, p. 109) como instância cuja incompletude identitária fomenta a procura de si dentro dos limiares do contato.

Da descrição do início ao ponto final no casamento, o narrador exercita a tarefa de (re) ler o "lírico e prático” (ROSA, 1979, p. 109) trazido na atitude de Quim e Rita, costurando tangências de como o chinês guardava, de um lado, em si a pulsão de transgredir os pactos da referencialidade do lirismo como meio para acessar a estrangeiridade do mundo em movimento. De outro lado, Rita fixa-se, inestancavelmente, no simples "sentar numa cadeira" (ROSA, 1979, p. 109) e saborear a humanidade no sertão da memória individual e coletiva. Entre um e outro mundo de revelações axiomáticas, o narrador costura o saber de que "o amor é breve ou longo, como a arte e a vida" (ROSA, 1979, p. 109). Os lances de ressemantização da longevidade e brevidade do amor de Quim e Rita são as âncoras de fixação relativa para que sejam estendidas as ranhuras do movimento interativo. Pode-se seguir, a propósito, o diâmetro do entendimento de que Quim ocupa o território da arte e Rita o da vida.

Não obstante a situação binária, a ótica da transliminaridade domina a percepção dos protagonistas. $\mathrm{O}$ arremate do narrador é magistral, quando textualiza hipóteses assentadas entre "a sovinice da vida, as inexatidões do concreto imediato, ou o mal-hálito da realidade” (ROSA, 1979, p. 110). Atente-se, agora, à estratégia triangular acionada com os signos moventes: sovinice, inexatidão e mal-hálito. Com tais ângulos, o narrador rotaciona e translada a relação entre ficção e realidade, colocando Quim e Rita no limiar interativo. Noutras palavras, a dupla passa a experimentar o prazer de adulterar as fronteiras do mundo, aprendendo a lidar com a estrangeiridade no casamento, conhecimento e discurso 
partilhados em tensão. A comunhão das experiências efetiva-se, assim, na recepção de situações-limites cuja porosidade contempla a ética dos desvios como premissa para (re) elencar epistemologias transversais.

A ética do desvio viria da proposta de triangulação entre sovinice, inexatidão e mal-hálito, tanto da realidade quanto da ficção. Como laboratórios do fazer, conhecer e sentir, o mundo relacional das personagens desalinha qualquer tentativa de defesa de separação entre vida e arte. Sugerindo o distanciamento da conjunção alternativa ou, como recurso de exclusão de um dos pontos de vista, e confeccionando o convite à inserção da coordenativa aditiva e, enquanto marcador de deslocamento cuja semântica joga com o princípio da interação, o narrador amplia as redes de disjunção de Quim e Rita.

$\mathrm{O}$ anúncio da separação vem embalado pela sintaxe da mobilidade cultural e linguística: "Desertou dele. Discutiam, antes - ambos de cócoras; aquela conversação tão fabulosa. E nunca há fim, de patacoada e hipótese” (ROSA, 1979, p. 110). Há, com isso, a ampliação da nomadologia multiterritorial que guia o narrador, preocupado, neste instante, em traduzir os desdobramentos do verbo desertar e dos substantivos cócoras e conversação. Ao sair da tutela do chinês, Rita continua a caminhada por dentro das esferas de sua estrangeiridade, ao passo que o marido também expande seu roteiro de viagem pelas culturas em movimento. Na cena das cócoras, o comportamento dos dois expressa a relativização da superioridade de um sobre o outro, ambos se encontram no mesmo patamar de enunciação das trocas e transferências subjetivas.

De tal camada semântica, brota a mutabilidade do chinês e da brasileira, trilhando os intervalos das línguas do amor, vida e cotidiano no sertão-mundo. Com um sinal percuciente - o de que não há fim na circulação dos processos de trocas entre as culturas - o narrador explora a trajetória de Quim e Rita como uma metonímia-valise de outras redes de contato, abrindo rotas para que sejam redescobertas fendas no pensamento em diálogo. Pela voz da brasileira, afirma-se a transmigração entre vida e arte. Embora não dada ao jogo das sínteses, a voz de Rita recorta paroxismos e versões holísticas que, muitas vezes, escapam o fino trato da escrita.

Ao viverem a contradição do mundo em transformação, Quim e Rita expressam a resenha dialógica dos imaginários. Da entrada à saída de Quim, "Rita-a-Lola, em tanto quanto, apesar de si, mudara, mudava-se" (ROSA, 1979, p. 110) A ética do contato joga Rita nas ecologias transterritoriais, fazendo-a participante da geografia de afetos pensados para além do lugar como singularidade, mas também a cartografia dos paradoxos de sujeitos posicionados no interstício da estrangeiridade planetária. A voz de Rita ecoa, mais uma vez, para oferecer escalas de leitura sobre a interconexão das culturas: "De que banda é que aquela terra será? (ROSA, 1979, p. 110) O tom interpelativo procura acender as latitudes do mundo, convidando à migrância dos sentidos. Terra aí carrega a dimensão do sujeito que nela desenvolve as práticas cotidianas, aprendendo a ir aquém da objetificação do pensamento monolítico, mas principalmente exercitar as nomadologias multiterritoriais da humanidade no contemporâneo.

Trançando a voz e o sentimento descentrado de Rita, o narrador continua o processo de mediação dos imaginários: “Apontou-se-lhe, em esmo algébrico, o rumo do Quim chim, Yao o ausente, da Extrema-Ásia, de onde oriundo: ali vivem de arroz e sabem salamaleques” (ROSA, 1979, p. 110). Sem as coordenadas certas, e isso é importantíssimo, pois sublinha a perda dos valores absolutos de dominação do outro, Rita experimenta a (geo)grafia imprecisa do itinerário do ex-marido. O percurso de "Quim chim", "Yao o au- 
sente” (ROSA, 1979, p. 110) evidencia o trânsito das línguas portuguesa e chinesa, vindo marcadas no nome-alteridade localizado nos interstícios das trocas culturais. O adjetivo "ausente" expressa uma aprendizagem outra instalada em Rita, continuando presente o chinês na consciência interfronteiriça da ex-esposa.

Posta em primeiro plano a condição do sujeito em deslocamento nas dobras próprias e alheias, o narrador desliza pela Extrema-Ásia, destrançando linhas de fuga em torno da cultura chinesa, com a prática do cultivo do arroz e a travessia também pelas práticas muçulmanas, a exemplo do termo salamaleques. De dentro da cultura do sertão, o narrador olha para além da China povoada por outros mundos cujas representações rompem com atavismos culturais. A costura dos mundos oriental e ocidental pode ser encontrada ainda em Rita, com a "pele, até, com reflexos de açafrão" (ROSA, 1979, p. 110). Tatuada no corpo, a cultura alheia torna-se coparticipante da territorialidade mineira, alçada em sua dimensão plural de liquefazer-se fronteiriçamente.

A nomadologia multiterritorial alicerça-se na transmigração entre a axiologia e a prospecção de espaços textuais onde acontece a travessia pelo mundo em metamorfose. No itinerário de Rita, fica patente “Outr'algo recebera, porém tico e nico: como gorgulho no grão, grão de fermento, fino de bússola, um mecanismo de consciência ou cócega. Andava agora a Lola Lita com passo enfeitadinho, emendado, reto, proprinhos pé e pé" (ROSA, 1979, p. 110). Receber e ultrapassar as fibras do continente, lugar e arquipélago da diferença constitui uma das linhas de fuga adotada pelo narrador rosiano, ao lançar sobre a superfície da textualidade palavras-território, sentidos-lugar e sujeitos-trânsito.

Amparados em acordes dissonantes, os quarenta e cinco parágrafos de Um Oriental na Vastidão fogem ao sentido congelado das trocas culturais na floresta-mundo, pondo em evidência o traçado de um mapa ficcional habitado por horizontes provisórios, fracionados pelo agenciamento da transmigração interplanetária. Através da narração de uma pesquisadora da Universidade do Amazonas, o conto cartografa a poética da conexão entre América e Ásia em Manaus, através da deambulação dos estrangeiros Kazuki Kurokawa, cônsul e secretário, com ou sem a parceria dos manauaras Américo e a narradora, na imensidão da floresta-mundo hatouniana.

O texto abre com a voz de um estrangeiro se espalhando na ligação telefônica recebida pela narradora. $\mathrm{O}$ cônsul do Japão solicita um encontro, no porto de Manaus, às duas horas, no barco do consulado, com a pesquisadora manauara. Seco em sua performance narrativa, o japonês apenas cita o nome Kazuki Kurokawa, acendendo a memória da narradora para relembrar quem era essa passante. Colocando em suspenso uma primeira voz oriental, a pesquisadora-narradora desce às camadas do passado para trazer à superfície o volume de outra dicção nipônica.

Professor aposentado da Universidade Tóquio, Kazuki tinha o sonho, desde a infância, de conhecer o rio Negro. Remete, então, um fax ao Departamento de Cooperação Científica da Universidade do Amazonas. Através da leitura do currículo do estrangeiro, a narradora consegue mapear a trajetória do oriental: "biólogo de água doce, com experiência de campo na África portuguesa e nas Filipinas” (HATOUM, 2009, p. 29-30). Nessa situação inicial, percebe-se a interligação dos multiterritórios administrativo e intelectual das personagens: cônsul e professor e pesquisadora. Esse trio tem suas vidas figuradas pelo tecido permeável das transformações dos lugares. Japão e Brasil participam, assim, de uma cartografia verbal cujas situações-limite deslizam pela memória do contato.

A entrada de Kazuki, no universo brasileiro, dá-se através de um voo de vinte e quatro horas, três escalas e fácil adaptação ao fuso horário da territorialidade amazônica. Ao 
primeiro contato com a narradora, Kazuki lhe presenteia com "um pequeno estojo de madeira. Dentro do estojo vi um rolinho de papel-arroz com ideogramas" (HATOUM, 2009, p. 30). Entre a elasticidade da voz e corpo, os signos da cultura japonesa avançam na escrita. Recebendo o presente, a pesquisadora não consegue compreender os ideogramas, levando Kurokawa, com sotaque português, a traduzir como "No lugar desconhecido habita desejo" (HATOUM, 2009, p. 30). O sistema de escrita oriental aponta como tudo entra em conexão no imaginário dos pesquisadores, puxando-os para o cenário de transmigração em torno da adoção de uma cominatória de práticas culturais oblíquas.

Realizado no aeroporto de Manaus, esse primeiro contato se amplia no trânsito pelo espaço urbano. Com apenas uma sacola como bagagem, Kazuki atravessa as ruas manauaras, passando pela frente do Teatro Amazonas, admirando-o em silêncio. O porto também é um lugar por onde os pés do nipônico caminham para entrar na fluidez do mundo aquático. Preocupada em aplainar os trilhos da entrada no rio, a narradora acena para que o barqueiro Américo se ponha a postos para conduzir o itinerário da viagem. Mas Kurakawa desgarra-se, momentaneamente, da companhia da guia, entrando no universo do Mercado Municipal. Esse desvio de rota indica a fronteira da hibridez do pesquisador, que procura absorver a importância de paradas-limítrofes para compreender os traços de humanidade existentes no espaço público manauara.

Alimentação e sujeitos estão no raio de tradução do mundo diferente acessado nas leituras sobre a territorialidade latinoamericana, mas que precisa ser visualizado, sentido e interpretado consoante o trânsito in loco pelas zonas de fluxos deslocados. À proporção que se desloca, Kazuki dialoga com, por exemplo, uma cabocla e ri quando aponta para o próximo horizonte a ser habitado: o rio. A caminhada até o barco acontece com passos bem ligeiros, começando a viagem de reconhecimento do mundo, vindo, agora, à baila com personagens, paisagens outras.

Desprovido de parafernálias tecnológicas, o japonês, no meio do rio, começa a desfiar o rosário do conhecimento sobre o espaço aquático à vista, desencadeando, em Américo, certa surpresa quanto à perícia do professor. Esse, numa atitude de reconhecimento da estranheza do guia do barco, esclarece que lera textos sobre a fauna e flora do Rio Negro. Diante desse contexto de revelações, a narradora segue a cartografia da viagem de reconhecimento do japonês, pondo em evidência os multiterritórios da experiência cuja mão alheia não pode dar cabo da aprendizagem individual. A viagem, na companhia dos manauaras, não foi suficiente para que o oriental descobrisse os fragmentos internos atinentes a ele mesmo, tanto que não arreda o pé do porto.

A transmigração de Kazuki precisava ser realizada sozinho, tendo como guia as descobertas singulares. Na despedida da pesquisadora, a fala do estrangeiro é profética: "Vou voltar... Um dia vou voltar e a senhora será convidada para fazer outro passeio" (HATOUM, 2009, p. 32). A escala do retorno sentencia o convite de translado futuro. Do presente, o japonês tece as tramas do alhures, costurando redes de afetos ao lugar. Nesse presságio, dá-se o distanciamento entre o japonês e a pesquisadora. O olhar extasiado de Kurokawa perante as margens do rio Negro e Amazonas fica alojado na urdidura do pensamento da narradora.

No reencontro com Américo, meses depois, o barqueiro esclarece as consequências da travessia individual do homem de longe: "moreninho, parecia um caboclo de cabeça branca. E ainda aprendeu umas palavras da nossa fala. Me disse: Obrigado, mano, teu barco é pai-d'égua [...] agradeceu em japonês e deu adeus com um sorriso miúdo. Eu dis- 
se: Arigatô, saionara" (HATOUM, 2009, p. 33). A multiterritorialidade se metamorfoseia no deslocamento da pigmentação do corpo do japonês, agora caboclo com a textura branca do cabelo. Da epiderme em mutação, acontece a migração pela língua cotidiana dos ribeirinhos. Todavia, ao despedir-se, volta a migrar pela língua japonesa, abrindo brecha para que Américo se lançasse à aventura de arranhar algumas palavras na língua oriental. Os rearranjos linguísticos articulados pelos dois transeuntes evidenciam o transbordar das fronteiras culturais, dando volume à porosidade efêmera das linhas em diagonal da vida.

Contextualizada a passagem, a despedida e a andança de Kurokawa, a narradora volta à teia do encontro com o cônsul e o secretário, "vestidos de terno e estavam muito sérios" (HATOUM, 2009, p. 33). A presença da bandeira do Japão entre as do Amazonas e Brasil é bem sugestiva, pois multiterritorializa os eventos da relação intercultural. A poética do contato se expande, com a segunda travessia da narradora, no momento em que "O comandante apontou o mapa: paraná da Paz. [...] Era um remanso grande, quase um lago, belo como um lago de águas espelhadas. Um círculo de águas calmas" (HATOUM, 2009, p. 33). O trânsito das culturas se estabelece mais fortemente, dotando as personagens de devires acionados a partir da teatralização das diferenças entre os mundos de lá e cá da experiência transterritorial.

Mais uma vez, a narradora estará imersa na abertura de uma caixa de madeira, não mais com os ideogramas, mas sim com as cinzas do pesquisador. A carta-testamento deixada por ele apontava duas direções: seus restos mortais deveriam ser jogados nas águas do Rio Negro e que isso fosse feito pela pesquisadora da Universidade de Amazonas. Metonímia do governo japonês, o cônsul tira do bolso uma bússola, virando, junto com o secretário, para o ponto oposto ao do crepúsculo. O pedido para que as cinzas fossem espalhadas, com bastante vagar, revela o traço ritualístico da cerimônia de multiterritorialização do biólogo no ecossistema das águas amazônicas. A liquidez é o ponto de consistência da transumância de Kazuki, desenhando linhas de fuga a partir do dueto do hino japonês, entoado no momento em que a narradora enchia as mãos de cinza e as lançava na água.

A poeticidade instala-se na ecologia limiar no instante em que "o sol sumia na selva, deixando um vestígio vermelho na natureza. Em silêncio, eles contemplaram o outro lado do horizonte e curvaram o corpo. Eu os imitei". (HATOUM, 2009, p. 33). Os elementos da natureza - sol e selva - acessados para além dos recursos territoriais - promovem uma cartografia alargada da cor do crepúsculo do dia. Esse vermelho, com o traço oblíquo, tece uma rede inacabada com a cultura japonesa na imensidão da floresta-mundo, rio e remanso do desejo de transmigrar pela estranheza do retramar das multiterritorialidades. A contemplação do outro lado do horizonte desmarca os referentes espaço-temporais, entrecruzando corpos, línguas e discursos na trama das diferenças. Passando vidas a limpo nos encontros, a narradora "imita", a seu modo disjuntivo, o gesto de curvar-se à celebração da poética das multiterritorialidades. A recordação dos ideogramas, com a inscrição "no lugar desconhecido habita o desejo" (HATOUM, 2009 , p. 33) apostrofa a habitação do devir em trânsito como forma de imaginar o inimaginável através da pulsão do movimento.

As redes interativas da floresta-mundo alcançam o ápice no testemunho final da narradora: "indaguei calada a razão misteriosa das cinzas do cientista no fundo do rio Negro. Não havia mais claridade, e a superfície escuta alcançava o céu” (HATOUM, 2009, p. 33). A atmosfera do movimento consolida uma visão múltipla do gesto articulatório das mentalidades projetadas na diligência comportamental e cultural da narradora-pesquisa- 
dora, dotando-a de acepções axiomáticas cujas envergaduras contextuais tecem outras diretrizes enunciativas para o percurso da cooperação literária.

Como formas de habitar o mundo das mobilidades, os contos rosiano e hatouniano expressam "a diferença que margeia o texto literário e o constitui como tal não se define por uma originalidade intrasferível, mas é antes a marca da retomada intermitente de uma cultura sobre a outra" (MIRANDA, 1998, p. 13). Ao instalarem-se na provisoriedade e fragmentação dos imaginários, os narradores dos dois textos circulam pela constelação das transferências interculturais, experimentando o signo da encruzilhada de nomadologias multiterritoriais para narrarem, em trânsito, a cartografia de vozes, línguas e encontros transculturais entre alteridades moventes.

\section{Considerações finais}

A imagem da quebra de limites tem sido explorada, em grande escala, na narrativa contemporânea, colocando em cena um entre-espaço cultural figurado como abismo de si e do outro. Essa escrita tem empreendido uma cartografia de negociações, mediações e traduções culturais, configuradas desde a relação entre o estranho e o conhecido como formas de reconhecê-los no solo da estrangeiridade. As situações de trânsito de figuras intercambiantes reconfiguram a fascinação inquietante entre a rejeição e hospitalidade do outro, pondo em relevo intercruzamentos espaciais e temporais cuja imagem heterotópica explora as significações do movimento.

A performance do estrangeiro contribui para compreender a tensão da fala de "fora" e "dentro" derrubando as fronteiras de uma pedagogia da unicidade e mapeando uma nação intersticial (BHABHA, 1998). As falas em suspensão indicam a fragilidade da soberania das culturas nacionais e o perigo de um pretenso universalismo da experiência humana. O confronto entre uma geografia inventada e uma geografia real projeta uma virtualidade contingente de culturas, tornando possível a construção de um espaço textual cujas condições de enunciação reconstituem não-saberes, não-lugares e as situações-limites da singularização cultural que resiste à totalização.

Essa enunciação descentrada lança mão de expedientes interculturais impulsionados por outras maneiras de articulação estética. Nessa perspectiva, a performatividade epistêmica e ficcional do pensamento da estrangeiridade se apresenta como processo de significação no qual se afirmam campos de força distintos e princípios de representação. Daí a emergência do imaginário da estrangeiridade como redefinição ininterrupta do valor do contato cultural, linguístico e afetivo. As narrativas desenvolvem, assim, a ética contrapontual entre deslocamento, distanciamento e razão contingente dos diálogos friccionais da nação híbrida.

A interface do imaginário é chave usada pelas personagens para perceber a estrangeiridade de lugares, espaços, paisagens a brotar de perguntas, afirmações, exclamações, pontos seguidos lançados em meio ao itinerário desviante de sujeitos cuja vivência i-lógica da fricção expõe o risco e a necessidade de cartografar a estrangeiridade da própria casa, no interior de suas subjetividades. Os contatos com os da nação em trânsito abalam as certezas de suas identidades, bem como a própria realidade imaginada e vivida. Essa é transformada em porto de reflexão da vivência interna do outro da própria pátria dentro da identidade desmedida, fracionada e intercambiada que ambos pactuam una e diversamente. 
O imaginário da escrita acessa, dinamicamente, à solidariedade disjuntiva tornada rede de estranheza cuja proximidade margeia a compreensão do mundo partilhado como possibilidade de diferença em interação. O encontro com os outros da nação em situação (in)fronteiriça aciona o outro de si de narradores em trânsito, de tal forma a estabelecer reconversões intersubjetivas, postuladas consoante mapas redigidos desde as fricções das estrangeiridades como zona de contingência abismal de sujeitos em formação e interagindo através de rearranjos incontornáveis.

Os textos lançam-se em aventura intersemiótica para escavar o universo da arqueologia da estrangeiridade, não como um viajante que busca homogeneizar as diferenças, mas como um ser de passagem que escolhe viver a própria estrangeiridade em ação. As personagens e narradores rosiano e miacoutiano estão em movimento, eles são em movimento. Seus respectivos projetos de tradução do mundo, também em mobilidade, espalham, transbordam e relançam a importância da desleitura da voz homogênea em que, muitas vezes, procuramos ancorar na comunidade fechada. Ela é aberta à marca existencial, ética e política de contrapontos de olhares, como faces de uma mesma moeda do espaço em transição. Os rastros da estrangeiridade partilhada refletem os fragmentos do mundo cuja cartografia dos territórios sobrepostos, das línguas em tensão, das itinerâncias estéticas impulsiona a circulação da identidade multifacetada como condição de ser em constante movimento.

O imaginário dos narradores é, por consequência, distanciado da clausura monológica, aliançando-se à situação de estrangeiridade da nação híbrida. As dobras da linguagem inscrevem outros gestos de diferença em diálogo, registrando intersubjetividades marcadas indelevelmente pela heterogeneidade cultural. É nessa zona de encontro que se estabelecem os narrares em trânsito. A linguagem da estrangeiridade é uma maneira de os narradores responderem ao estrangeiro, à nação una com a própria palavra desses, uma espécie de "tudo que você disser será usado contra você".

Esse modo de escrever em movência confere aos textos a percepção da estrangeiridade como ponto de heterogeneidades vazado no exercício da linguagem. Tanto o estrangeiro quanto a nação são construções imaginárias que se veem confrontadas com suas próprias incompletudes e pontos de fuga que os fazem reconhecer a estrangeiridade do mundo em conexão. Seus discursos falham, suas experiências perdem o sentido das totalizações. Ao problematizar os códigos da homogeneidade, os saberes dos narradores flagram a ruptura dos limites como verve para desviar-se da recuperação original de seres e paisagens, figurando-os em consonância com as linhas de fuga, como diria Deleuze, de uma ressignificação mediada pela imagem de um olhar em trânsito.

Deslocadas da busca de fixação, antes sim embaladas pelos entrecruzamentos espaciais e temporais, as vozes dos narradores içam a ética da possibilidade de estar em deslocamento. Essas dicções são instâncias prospectivas através das quais tornam-se viáveis os meios para promover a ruptura com a estereotipia da identidade nacional acabada, agudizando a dinâmica da complexidade dos imaginários desviantes, insubmissos e polifônicos.

Dotados de múltiplas redes intelectuais, Guimarães Rosa e Milton Hatoum são escritores cujo plano de travessia estética e cultural se revela a partir da plurivocalidade transcontinental. Seus lugares da ficção são vazados pelo trânsito no mundo oral, pela errância nas paisagens do contato, pelos desvios das passagens, pela transumância de vozes e pela cartografia do sertão-mundo e floresta-mundo cujo lar alberga estrangeiridades e desenha liminaridades através da elaboração de mapas onde as margens do sertão e floresta se liquefazem para hospedar humanidades em devir. 
Pelo movimento nomadológico, as narrativas rosianas e hatounianas desenvolvem uma sintaxe da deriva, potencializam o signo das migrações, topografam uma semântica da itinerância, franqueiam uma despressurização da língua, mapeiam o deslocamento das alteridades, grafam o rascunho dos andarilhos, encenam a dicção da heterogeneidade e trafegam pelo labirinto da dimensão holística da Arte, Vida e Escrita. Entre as interfaces dessa triangulação, a literatura dos dois autores deriva, bordeja e reelabora a geograficidade da voz e a textualidade do território em sua tonalidade plurissignificativa.

Reveladores de outras latitudes e longitudes do mundo em fricção, os textos-mapas de Rosa e Hatoum arremessam o leitor nas redes do lugar de fala, bem como escalam o princípio de que o território se constrói no movimento contínuo e dinâmico. A articulação em rede faz da escrita um território para onde conflui uma multiplicidade de ritmos, sons e vidas posicionados no limiar dos sentidos. As fronteiras atravessadas são um território ritualístico cuja aprendizagem transborda as frações do lugar, acessando-o a partir da conjunção disjuntiva de outras fraternidades impressas no corpo da linguagem e tatuadas no roçar das temporalidades.

Do arremesso à atividade leitura à reconstrução dos impasses das interações, o texto-mapa se apresenta como um vir a ser, provendo (des)encontros inusitados entre culturas, línguas e ecologias. Instala-se, assim, a geograficidade da polifonia do olhar lançado sobre, através e desde a textualidade do território da solidariedade. Nessa perspectiva, os contos rosiano e hatouniano impulsionam o (des)encontro de múltiplas habitabilidades. O itinerário dos narradores desloca as temporalidades da consciência intervalar e amplificam os feixes com a opacidade para tirar partido das triangulações dos contatos, tornados albergues da pluralidade. A multiterritorialidade maximiza, assim, pertencimentos relativos cujas ressonâncias irmanam do trânsito das alteridades.

A transconexão entre lugar, língua, homem e imaginário flagra a heterogeneidade, remodelando o pensamento das geograficidades disfônicas e transpoéticas, rascunhadas no reterritorializar de leitores em constante (re)descoberta de outros horizontes de expectativa. Do singular ao plural, a diferença entre sertão e floresta realinha a reserva de monovocalidade para habitar o enclave das semióticas residuais que abrem o chão (geo)texto para a projeção de fraturas e estranhamentos prospectivos. O ápice desse alhures do imaginário captura a transmigração das metonímias da voz e internomadologias do sentido, cuja ida e vi(n)da do homem estica os laços intersemióticos das culturas. Inclusive, a tradução das adjacências estéticas dos narradores aponta o percurso da memória do contato, redefinindo os lugares a partir das pegadas do indivíduo posicionado no limiar da diferença.

Nos contos, a polifonia da geograficidade coloca, portanto, em circulação a consciência das ambiguidades, triangulações e opacidades do mundo contemporâneo. Não por acaso, as trocas culturais aproximam as espacialidades em sua extensão textual e simbólica, contemplando a conexão intervalar dos imaginários. O limiar crítico contempla, consequentemente, a absorção de respostas inacabadas, pois o grau de transbordamento aponta para o constante (re)simbolizar e (des)tramar do discurso, com suas estratégias de dinamização da multiterritorialidade de ecologias, línguas e imaginários planetários.

Em nomadologia oblíqua e diagonal, a literatura movimenta-se para além das geografias físicas, procurando escalar mapas-redes, sertões-mundo e florestas-mundo onde o (des)encontro não seja o ponto final, mas sim a elaboração de bússolas cujos ponteiros indiquem as reticências do entre-lugar de vozes, textos e culturas nuançados pela nomadologia de imaginários em rede. 
Referências

ALMEIDA, Sandra Regina Goulart. Da hospitalidade e do abjeto: percepções do estrangeiro. In: Graciela Ravetti; Maria Zilda Cury; Myriam Ávila. (Org.). Topografias da cultura: representação, espaço e memória. Belo Horizonte: Editora UFMG, 2009, p. 63-73. BARTHES, Roland. O grão da voz. Porto: Edições 70, 1982.

BERND, Zilá. Afrontando fronteiras da literatura comparada: da transnacionalidade à transculturalidade. Revista Brasileira de Literatura Comparada, 2013., v. 1, p. 211-222. BESSIÉRE, Jean. Centro, centros: novos modelos literários. In. WEINHARDT, Marilene; BHABHA, Homi. O Local da Cultura. Trad. Myriam Ávila. Belo Horizonte: Editora UFMG, 1998.

CARDOZO, Maurício Mendonça (Org.). Centro, centros. Literatura e Literatura Comparada em discussão. Curitiba: Ed. UFPR, 2011, v. 1, p. 13-35.

CARVALHAL, Tania. O próprio e o alheio: ensaios de literatura comparada. São Leopoldo: Editora UNISINOS, 2003.

CASA NOVA, Vera. Fricções: traço, olho e letra. Belo Horizonte: Editora UFMG, 2008. CHIARELLI, Stefania. As paisagens sonoras de Samuel Rawet. In: Chiarelli, Stefania; Oliveira Neto, Godofredo. (Org.). Falando com estranhos - o estrangeiro e a literatura brasileira. 1aed.Rio de Janeiro: 7letras, 2016, v., p. 95-106.

COLLOT, Michel. Rumo a uma geografia literária. In: ALVES, Ida; MELLO, Maria Elizabeth Chaves. (Org.) Gragoatá. Niterói, EdUFF, 2012.

CORACINI, Maria José. A celebração do outro. Arquivo, memória e identidade: línguas (materna e estrangeira), plurilingüismo e tradução. Campinas: Mercado das Letras, 2007. CURY, Maria Zilda Ferreira. Imigração no feminino: Amrik, de Ana Miranda. In: CHIARELLI, Stefania; OLIVEIRA NETO, Godofredo. (Org.). Falando com estranhos: o estrangeiro e a literatura brasileira. 1ed.Rio de Janeiro: 7Letras, 2016, v. 1, p. 140-158. . De orientes e relatos. In: SANTOS, Luís Alberto; PEREIRA, Maria Antonieta. (Org.) Trocas culturais na América Latina. Belo Horizonte: Pós-Lit/FALE/UFMG, 2000, p. 166-178.

DELEUZE, Gilles. Crítica e clínica. São Paulo: Editora 34, 2006.

FANTINI, Marli. Guimarães Rosa: fronteiras, margens, passagens. São Paulo: Ateliê Editorial, 2003.

GARRAMUÑO, Florencia. Nação e contaminação: tango, samba e diferenças culturas. In: SANTOS, Luís Alberto; PEREIRA, Maria Antonieta. (Org.) Trocas culturais na América Latina. Belo Horizonte: Pós-Lit/FALE/UFMG, 2000, p. 69-84.

GOMES, Renato Cordeiro. Janelas indiscretas e ruas devassas: duas matrizes para a representação da cidade. In. In: MARGATO, Izabel; GOMES, Renato Cordeiro. Org. Políticas da ficção. Belo Horizonte: Editora UFMG, 2015, p. 267-282.

HAESBAERT, R.. Território e Multiterritorialidade: um debate. GEOgraphia (UFF), v. 17, 2008, p. 19-45.

HALL, Stuart. Da diáspora: identidades e mediações culturais. Belo Horizonte: Editora UFMG, 2013.

HATOUM, Milton. A cidade ilhada. São Paulo: Companhia das Letras, 2009.

JOBIM, José Luís. Primeiras palavras sobre os sentidos dos lugares. In: JOBIM, José Luís. Sentido dos lugares. Rio de Janeiro, Abralic, 2005. 
MARGATO, Izabel. Os enredos do azar e fortuna: a charrua entre os corvos. In: MARGATO, Izabel; GOMES, Renato Cordeiro. Org. Políticas da ficção. Belo Horizonte: Editora UFMG, 2015, p.107-124.

MATTA, Inocência. Para uma geocrítica do eurocentrismo. In: FONSECA, Maria Nazareth Soares; CURY, Maria Zilda Ferreira. (Org.). África: dinâmicas culturais e literárias. Belo Horizonte: Ed.PUC-Minas, 2012.

MIRANDA, Wander Melo. Projeções de um debate. Revista Brasileira de Literatura Comparada, Florianópolis-SC, 1998, v. 4, p. 11-18.

MORICONI, Italo. Um pé na academia, outro no mercado: teoria e prática do ensino da literatura hoje. In: WEINHARDT, Marilene; CARDOZO, Maurício Mendonça (Org.). Centro, centros. Literatura e Literatura Comparada em discussão. Curitiba: Ed. UFPR, 2011, v. 1, p. 153-164.

PORTO, Maria Bernadette. Habitar a diáspora: representações do imaginário da distância em textos literários contemporâneos. Aletria, Belo Horizonte, 2012, v. 22, n. 3, p. 119-129.

ROSA, Guimarães. Tutameia: terceiras estórias. Rio de Janeiro, José Olympio, 1979.

REVUZ, Christine. A língua estrangeira: entre o desejo de um outro lugar e o risco do exílio. In. SIGNORINI, Inês (Org.) Lingua(gem) e identidade: elementos para uma discussão no campo aplicado. Campinas: Marcado das Letras, 1998.

SAID, Edward. Representações do intelectual - as conferências de Reith de 1993. São Paulo: Companhia das Letras, 2005.

SANTIAGO, Silviano. Nas malhas da letra. Rio de janeiro: Rocco, 2002.

Recebido em: 31/03/2019; Aceito em: 21/04/2019 